Original Research Paper

\title{
Influence of Cement Chemistry on the Performance of Cement Stabilized Tropical Lateritic Soil
}

\author{
Odumade Adegboyega Oduniyi, Ezeah Chukwunonye, \\ Charles Nnamdi Ezugwu and Ekeoma Emmanuel
}

Department of Civil Engineering, Faculty of Engineering and Technology, Federal University, Ndufu-Alike, Ikwo, Ebonyi State, Nigeria

Article history

Received: 12-04-2018

Revised: 07-05-2018

Accepted: 19-05-2018

Corresponding Author: Ezeah Chukwunonye

Department of Civil Engineering,

Faculty of Engineering and

Technology, Federal University,

Ndufu-Alike, Ikwo, Ebonyi

State, Nigeria

Email: C.Ezeah2@gmail.com

\begin{abstract}
Chemical composition affects overall performance of cement on other materials such as when used in concrete or for stabilization of lateritic soil. This research studied the influence of chemical composition of three Portland cement types represented as samples A, B and C on engineering performance when mixed with laterite under tropical environmental conditions. The Lateritic soil sample classified according to AASHTO as A-5(4) was collected from a typical tropical region. Performances of these cements were considered at different cementlaterite proportions, varying from $2-14 \%$. Parameters determined include chemical and metallic contents of the cements as well as Maximum Dry Density (MDD), California Bearing Ratio (CBR) and Unconfined Compressive Strength (UCS) of cement-laterite mixat a temperature range of $26-28^{\circ} \mathrm{C}$. One-way Anova test was used to validate the significant variation in the chemical composition of cements and the unconfined compressive strength. Results indicate that the bearing capacity and unconfined compressive strength of laterite - cement mix depend on the quantity of lime $(\mathrm{CaO})$ and silicon dioxide $\left(\mathrm{SiO}_{2}\right)$ content in the cement; results also confirm the influence of Aluminium Oxide $\left(\mathrm{Al}_{2} \mathrm{O}_{3}\right)$ and sulphur trioxide $\left(\mathrm{SO}_{3}\right)$ content on the setting time of cement.
\end{abstract}

Keywords: Chemical Composition, Portland Cement, Laterite, Setting Time, Bearing Capacity, Unconfined Compressive Strength

\section{Introduction}

Portland cement is the most common type of cement in general use around the world as a basic ingredient of concrete and also used as a stabilizing agent. It is a fine powder which is produced by heating limestone and clay materials in a kiln to form clinker, grinded and added to other materials. Portland cement is chemically composed of tricalcium silicate $\left(3 \mathrm{CaO} . \mathrm{SiO}_{2}\right)$, dicalcium silicate $\left(2 \mathrm{CaO} . \mathrm{SiO}_{2}\right)$, tricalcium aluminate $\left(3 \mathrm{CaO} \cdot \mathrm{Al}_{2} \mathrm{O}_{3}\right)$, tetracalcium aluminoferrite $\left(4 \mathrm{CaO} \cdot \mathrm{Al}_{2} \mathrm{O}_{3} \cdot \mathrm{Fe}_{2} \mathrm{O}_{3}\right)$ and calcium sulfate dihydrate orgypsum $\left(\mathrm{CaSO}_{4} \cdot 2 \mathrm{H}_{2} \mathrm{O}\right)$; and these oxides can be re-written with short notations which is used universally among cement scientists as $\mathrm{C}_{3} \mathrm{~S}, \mathrm{C}_{2} \mathrm{~S}$, $\mathrm{C}_{3} \mathrm{~A}, \mathrm{C}_{4} \mathrm{AF}$ and $\mathrm{CS} \mathrm{H}_{2}$ respectively, where Ŝrepresents $\mathrm{SO}_{3}$ (Amin, 2004).

Soil stabilization may be necessary where natural materials need to attain certain engineering characteristics before they could be used for constructions purposes e.g., in roads, dams and building construction. It has been reported that "lateritic soil in its natural state is not always suitable as base course for highway pavement design, however, its stabilization can bring improvement of the shear and compressive strengths while also reducing coefficient of permeability values" (Akiije, 2014).

Stabilization refers to the mixtures of soil and any cementitious material (s) with optimum amount of water, which result in a moist and dense mass with increased strength and bearing capacity. Several stabilizing materials such as cement, lime, flyash, bituminous materials etc., have been considered for improving the strength and other characteristics of laterite. Cement is reported to be one of the best stabilizers for civil engineering applications. The aim of this research is to study the influence of chemical constituents of cement on the properties of cement stabilized laterite by considering the strength of the cement stabilized laterite. Specifically, the research objectives include: 
1. To carry out chemical and metallic analysis on the three different cement types commonly used for soil stabilization

2. To separately stabilize the lateritic soil sample with the three cement types and investigate the effect of stabilization on engineering properties of laterite

3. To analyse the different chemical compounds of cement and their particular influence on the cement stabilized laterite

\section{Literature Review}

Previous studies have reported cement to be a good stabilizer for lateritic soils, however there are often different types and brand of cements available commercially based on chemical composition and uses, hence the need to examine the influenceof the chemical components of cement on the engineering performance of stabilized lateritic soils, so as to aid design engineers in decision making. ASTM C150/C150M -17 (2017), specified eight types of Portland cement: type I, IA, II, IIA,III, IIIA, IV and type V. Several properties of cement have been observed to influence the strength of concrete or cement stabilized material. For instance, Ahmad (2002) investigated the "effect of fineness of cement on properties of fresh and hardened concrete using six different finesses ranging from 169 to 333 $\mathrm{m}^{2} / \mathrm{kg}$ with clinker of same chemical composition"; henoted that "consistency and compressive strength of cement increased as fineness increases while setting times of cement decreased with fineness, no general relationship was established between fineness and expansion". It was also noted that "workability in terms of slump and compacting factor of fresh concrete increased as fineness increases; however, this result was significant up to 250 $\mathrm{m}^{2} / \mathrm{kg}$, after which values were insignificant".

The ideal compound stoichiometry is often used to calculate the composition of Portland cement while the oxide analysis can be done by standard methods such as X-ray fluorescence spectroscopy and can also be available from the cement manufacturer. Bogue calculation approach can be used to examine and quantify the presence of the different chemical compounds in the cement sample. Taylor (1997) said that "the values obtained by Bogue calculations are only approximate because Bogue calculations are based on a number of assumptions such as chemical equilibrium and the consistency in the composition of all the phases". Amin (2004) although said that "chemical equilibrium rarely occurs inside the kiln during cooling and found that a large number of substitutional ions can be incorporated in most of the phases. Thus, the phases do not have the compositions assumed for them. Nevertheless ASTM C 150 gives the Bogue calculations that are suitable for most purposes, although more sophisticated procedures have been developed".

Amin (2004) also reported that "the understanding of the compound constituents of Portland cement makes it possible to predict the properties of the cement, but more important is the fact that manipulation of the compound composition can be used to modify certain properties of the cement so that the cement will perform more satisfactorily in particular applications". $\mathrm{C}_{3} \mathrm{~A}$ and $\mathrm{C}_{3} \mathrm{~S}$ have more reactive abilities than other compounds, whereas $\mathrm{C}_{2} \mathrm{~S}$ is the slowest in reaction. The author also reported that "calcium silicates provide most of the strength developed by Portland cement; $\mathrm{C}_{3} \mathrm{~S}$ provides most of the early strength (in the first three to four weeks); while $\mathrm{C}_{2} \mathrm{~S}$ provides most of the ultimate strength and $\mathrm{C}_{3} \mathrm{~A}$ and $\mathrm{C}_{4} \mathrm{AF}$ control the setting time and the presence of gypsum slows the early rate of hydration of $\mathrm{C}_{3} \mathrm{~A}$ ".

Arimanwa et al. (2016) investigated the "effect of chemical composition of ordinary Portland cement on the compressive strength of concrete", the author adopted Scheffe's simplex technique to develop models to assess the compressive strength of the concrete produced from five different brands of Ordinary Portland cement available for construction works in South Eastern part of Nigeria. The authors noted from the results that "the chemical composition of cement as well as the mix proportions of the combining elements influenced the value of thecompressive strength of the resulting concrete"; and the authors also concluded from the study that "cement with identical chemical characteristics will produce concrete with similar compressive strength values. Jaritngam et al. (2014) in their study concluded that "the formation of reaction products, such as Calcium Silicate Hydrate (CSH) aids the strength development of the cement stabilized soil; and that the cement content influences the formation of these reaction products" - all of these were substantiated by experimental XRD patterns, SEM micrographs, UCS and CBR results; and that cement stabilization increasedsignificantly with the UCS and CBR of the lateritic soil sample (Solanki and Musharraf, 2012).

\section{Environmental Context}

Lateritic soil samples were collected from a borrow pit in Ogun State, South West Nigeria, an area with geology that represents typical tropical regions such as Nigeria. Key soil forming factors in this area such as climate, parent rock, topography, vegetation, are also typical of tropical environments. Temperature of the study area is also typical of tropical climates, varying between $26-30^{\circ} \mathrm{C}$ during the day and $22-24^{\circ} \mathrm{C}$ at night. Generally, the mean annual rainfall varies between 1500-2000 $\mathrm{mm}$ (Olaniran, 1991). Intensive rainfall is usually between June and September varying from 2500-3500 mm per year. This region is particularly known for heavy rainfall that encourages leaching and soil erosion. These climatic processes taking place alternately during the rain and dry seasons combine with other factors to form the type of soils called laterite (Odumade et al., 2018). 


\section{Materials and Methods}

Soil samplewas collected from a borrow pit in Ogun state, Nigeria. Sample wasclassified based on laboratory experiments as A-5(4) according to AASHTO classification, the natural optimum moisture content was recorded as $15.24 \%$. Three commercially available cements were considered for the investigation and are identified as Sample A, Sample B and Sample $\mathrm{C}$ respectively, these three cement types differ in chemical and metallic compositions and other properties such as fineness, standard consistency, initial and final setting time.

Several experiments were carried out on the cements to determine the fineness and other properties of cement. The standard consistency and setting time tests were carried out using the Vicat apparatus at room temperature, while the Cement fineness was measured using the sieve analysis with the residue of $0.045 \mathrm{~mm}$ measured. Chemical and metallic compositions were also analysed using XRF-cement spectrometer/cement analyser. Lateritic soil samples were stabilized with differing quantities of the three cement samples separately, considered at $2 \%$ interval of cement content from 0 to $14 \%$. Laboratory analyses were carried out on the laterite and cement stabilized laterite. These include sieve analysis; atterberg limits test; strength tests which includes compaction test, CBR test and UCS test.

Compaction tests were conducted with the natural soil samples as well as the cement stabilized soil, adopting a standard proctor test method. The methodology involved using a mould with $102 \mathrm{~mm}$ diameter which has a volume of $944 \mathrm{~cm}^{3}$, a hammer weighing $2.5 \mathrm{~kg}$ having a striking face of $51 \mathrm{~mm}$ in diameter and a $3000 \mathrm{~kg}$ of the lateritic dry soil sample that passes No.4 $(4.75 \mathrm{~mm})$ sieve, the water content was increased by $2 \%$ for each specimen.. The stabilized laterite soil-cement mixture sample was mixed with water and placed in three layers of about equal thickness and each layer was subjected to 25 blows from the hammer falling freely through a distance of $305 \mathrm{~mm}$ in the mould, trimmed at the surface and measured. The compacted sample with the mould was measured and after which part of it was taken near the center to oven dry for the purpose of determining the water content. Repeatprocedure continued by addition of more water in sequence of increment of $2 \%$ until the density decreases. The Maximum Dry Density (MDD) and Optimum Moisture Content (OMC) were determined at each cement content (Krishna, 2002).

The California bearing ratio tests were performed in the laboratory on the stabilized laterite soil-cement mixture sample by applying AASHTO T193 (2013) methodology after the standard Proctor test. At OMC, each soil-cement mixture sample was compacted in a mould of $152 \mathrm{~mm}$ diameter and $127 \mathrm{~mm}$ high and was immersed in water for four days with surcharge weight in place. Removing the sample from the water it was allowed to drain for a period of $15 \mathrm{~min}$. The same surcharge was imposed on the sample and immediately subjected to penetration by forcing a 19.4 $\mathrm{cm}$ plunger at the rate of $1.25 \mathrm{~mm} / \mathrm{min}$ into the sample to a depth of $2.5 \mathrm{~mm}$. CBR tests were carried out for both soaked and unsoaked samples.

The Unconfined Compressive Strength tests were also carried out for each cement content at OMC to determine strength values after the standard Proctor test. The soil sample was placed in three layers in the lubricated split mould, which was then coupled and given 25 number blows using the tamping rod, after which the soil was extruded and tested in the compression machine. UCS tests were carried out for uncured samples and samples air - cured for 7 days, 14 days and 28 days respectively.

All the laboratory experiments were carried out at the civil engineering laboratory, University of Lagos, Nigeria at a room temperature of $26-28^{\circ} \mathrm{C}$; while the water used to prepare the sample was potable water from municipal supply, clean and air-free.

Statistical analysis consisted of Anova test on key chemical parameters of cements and unconfined compressive strength of soils stabilized with $14 \%$ cement; this was done to ascertain if there is a significant difference in the UCS of the laterite stabilized with different cement types since the test procedures and environmental conditions during the test was relatively constant and the same type of laterite A-5(4) was used for the test.

\section{Results}

A breakdown of the results is given in Table 1, while Table 2 gives the breakdown of the major chemical compositions of the three cements according to Bogue's calculations which indicates the difference in their properties. Table 3 is a comparison of the tests results with the BS requirements and the results of other tests carried out on the cements such as standard consistencies etc. The sieve analysis of the soil sample isshown in Fig. 1; while the results of the compaction tests are shown with the graphs of MDD and OMC in Fig. 2; the results and graphs of the CBR tests are shown in Fig. 3. Figures 4 and 5 shows the results and graphs of the UCS tests for both uncured and cured samples respectively. Table 4 validates the fact that there is a statistical difference in the UCS of the soil according to the Anova test; while Table 5 validates the hypothesis that difference in the chemical composition of the cement influences the variation in strength of cement stabilized soil samples. 
Table 5 shows significant differences between the qualities of these cements in the terms of chemical composition. The values shown for the cement samples are mean \pm standard deviation. The mean values with different alphabetical superscript indicate a considerable difference $(\mathrm{p}$ value $<0.05)$.

Table 1: Chemical and metallic analysis of the lateritic soil sample and cements

\begin{tabular}{|c|c|c|c|c|}
\hline Parameter (\%) & A-5(4) & Sample A & Sample B & Sample C \\
\hline $\mathrm{SiO}_{2}$ & 44.240 & 19.9100 & 20.3500 & 22.210 \\
\hline $\mathrm{Na}_{2} \mathrm{O}$ & 0.046 & 0.4000 & 0.6400 & 0.500 \\
\hline $\mathrm{K}_{2} \mathrm{O}$ & 0.042 & 0.3500 & 0.3900 & 0.300 \\
\hline $\mathrm{CaO}$ & 0.030 & 63.5000 & 63.7400 & 63.820 \\
\hline $\mathrm{MgO}$ & 0.020 & 2.1700 & 2.0400 & 2.750 \\
\hline $\mathrm{BaO}$ & 0.000 & 0.0000 & 0.0000 & 0.002 \\
\hline $\mathrm{MnO}$ & 0.008 & 0.0000 & 0.0000 & 0.000 \\
\hline $\mathrm{Al}_{2} \mathrm{O}_{3}$ & 30.350 & 4.9200 & 4.4800 & 6.080 \\
\hline $\mathrm{Fe}_{2} \mathrm{O}_{3}$ & 0.054 & 0.7500 & 0.9100 & 1.240 \\
\hline $\mathrm{SO}_{3}$ & 0.000 & 1.0200 & 1.1400 & 1.230 \\
\hline Moisture & 2.670 & 0.0000 & 0.0000 & 0.000 \\
\hline $\mathrm{Ca}(\mathrm{OH})_{2}$ & 0.000 & 0.4100 & 0.5000 & 0.270 \\
\hline I R & 0.000 & 0.9960 & 0.9940 & 0.990 \\
\hline L. O. I & 0.006 & 0.0050 & 0.0170 & 0.026 \\
\hline $\mathrm{pH}$ & 0.000 & 12.3000 & 12.3000 & 12.100 \\
\hline Conductivity $\left(\mu \mathrm{Scm}^{-1}\right)$ & 0.000 & 2060.0000 & 3000.0000 & 7600.000 \\
\hline $\mathrm{SO}_{4}{ }^{2-}(\mathrm{mg} / \mathrm{kg})$ & 0.000 & 250.0000 & 460.0000 & 640.000 \\
\hline Organic Carbon (\%) & 0.000 & 0.8400 & 0.7200 & 0.560 \\
\hline $\mathrm{Cl}^{-}(\mathrm{mg} / \mathrm{kg})$ & 0.000 & 60.0000 & 1200.0000 & 1550.000 \\
\hline $\mathrm{Fe}(\mathrm{mg} / \mathrm{kg})$ & 0.038 & 0.4188 & 0.5081 & 0.692 \\
\hline $\mathrm{Al}(\mathrm{mg} / \mathrm{kg})$ & 16.070 & 1.3280 & 1.2090 & 1.640 \\
\hline
\end{tabular}

Using Bogue's Equation

$\mathrm{C}_{3} \mathrm{~S}=4.07(\mathrm{CaO})-7.60\left(\mathrm{SiO}_{2}\right)-6.72\left(\mathrm{Al}_{2} \mathrm{O}_{3}\right)-1.43\left(\mathrm{Fe}_{2} \mathrm{O}_{3}\right)-2.85\left(\mathrm{SO}_{3}\right)$

$\mathrm{C}_{2} \mathrm{~S}=2.87\left(\mathrm{SiO}_{2}\right)-0.754\left(3 \mathrm{CaO} \cdot \mathrm{SiO}_{2}\right)$

$\mathrm{C}_{3} \mathrm{~A}=2.65\left(\mathrm{Al}_{2} \mathrm{O}_{3}\right)-1.69\left(\mathrm{Fe}_{2} \mathrm{O}_{3}\right)$

$\mathrm{C}_{4} \mathrm{~A}=3.04\left(\mathrm{Fe}_{2} \mathrm{O}_{3}\right)$

Table 2: Breakdown of compound composition according to Bogue's calculations

\begin{tabular}{lcrr}
\hline Compound Composition & Sample A & Sample B & Sample C \\
\hline $\mathrm{C}_{3} \mathrm{~S}$ & 78.83 & 70.10 & 44.81 \\
$\mathrm{C}_{2} \mathrm{~S}$ & 4.23 & 5.30 & 29.91 \\
$\mathrm{C}_{3} \mathrm{~A}$ & 11.56 & 10.16 & 14.06 \\
$\mathrm{C}_{4} \mathrm{AF}$ & 2.25 & 2.79 & 3.77 \\
$\mathrm{C}_{3} \mathrm{~S} / \mathrm{C}_{2} \mathrm{~S}$ & 17.71 & 12.67 & 1.50 \\
\hline
\end{tabular}

Table 3: Compliance of cement brands to British standards requirements and other tests on cements

\begin{tabular}{|c|c|c|c|}
\hline & Sample A & Sample B & Sample C \\
\hline $\mathrm{CaO}+\mathrm{SiO}_{2} \geq 50 \%(\mathrm{~m} / \mathrm{m})$ & 83.410 & 84.09 & 86.03 \\
\hline $\mathrm{CaO} / \mathrm{SiO}_{2} \geq 2$ & 3.190 & 3.130 & 2.87 \\
\hline $\mathrm{MgO}$ Content $\leq 5 \%(\mathrm{~m} / \mathrm{m})$ & 2.170 & 2.040 & 2.75 \\
\hline $\mathrm{SO}_{3}$ Content $\leq 3.5(+0.1) \%$ & 1.020 & 1.140 & 1.23 \\
\hline Loss on Ignition $\leq 3.0(+0.1) \%$ & 0.005 & 0.007 & 0.026 \\
\hline Initial Setting Time $\geq 60(-15)$ (mins) & 85.000 & 90.000 & 74.00 \\
\hline Final Setting Time (mins) & 204.000 & 215.000 & 195.00 \\
\hline Standard Consistency (mins) & 3.000 & 3.000 & 5.00 \\
\hline$\%$ Standard Consistency & 32.500 & 28.750 & 35.00 \\
\hline Total Percent Concentration & 95.270 & 95.910 & 99.98 \\
\hline
\end{tabular}

Table 4: Statistical validation of variations in UCS values for the three cement stabilized laterite samples

\begin{tabular}{lccrr}
\hline Days & Sample A & Sample B & Sample C & F(P-Value $)$ \\
\hline 7 & $1373^{\mathrm{a}} \pm 4.3300$ & $1585.94^{\mathrm{b}} \pm 1.04$ & $1608.02^{\mathrm{c}} \pm 3.10$ & $5050.06(0.0000)$ \\
14 & $1527.24^{\mathrm{a}} \pm 2.53$ & $1665.65^{\mathrm{b}} \pm 2.53$ & $1694.97^{\mathrm{c}} \pm 2.09$ & $6099.928(0.000)$ \\
28 & $946.00^{\mathrm{a}} \pm 4.21$ & $1004.2^{\mathrm{b}} \pm 5.090$ & $994.61^{\mathrm{c}} \pm 9.10$ & $141.503(0.000)$ \\
\hline
\end{tabular}

The values shown for the cement samples are mean \pm standard deviation. The mean values with different alphabetical superscript indicate a considerable difference ( $\mathrm{p}$ value $<0.05$ ) 
Odumade Adegboyega Oduniyi et al. / American Journal of Engineering and Applied Sciences 2018, 11 (2): 783.791 DOI: 10.3844/ajeassp.2018.783.791

Table 5: Statistical validation of the variation in chemical composition of the cements used for the study

\begin{tabular}{|c|c|c|c|c|}
\hline Chemical Constituents & Sample A & Samples B & Sample C & $\mathrm{F}(\mathrm{P}-$ Value $)$ \\
\hline $\mathrm{C}_{3} \mathrm{~S}$ & $78.83^{\mathrm{c}} \pm 0.97$ & $70.10^{\mathrm{b}} \pm 0.81$ & $44.81^{\mathrm{a}} \pm 0.64$ & $1467.942(0.000)$ \\
\hline $\mathrm{C}_{2} \mathrm{~S}$ & $4.23^{\mathrm{a}} \pm 0.20$ & $5.3^{\mathrm{b}} \pm 0.210$ & $29.91^{\mathrm{c}} \pm 0.23$ & $13921.315(0.000)$ \\
\hline $\mathrm{C}_{3} \mathrm{~A}$ & $11.56^{\mathrm{a}} \pm 0.21$ & $10.16^{\mathrm{b}} \pm 0.17$ & $14.06^{\mathrm{c}} \pm 0.08$ & $449.322(0.000)$ \\
\hline $\mathrm{C}_{4} \mathrm{AF}$ & $2.25^{\mathrm{a}} \pm 0.08$ & $2.79^{\mathrm{b}} \pm 0.03$ & $3.77^{\mathrm{c}} \pm 0.06$ & $377.187(0.000)$ \\
\hline $\mathrm{C}_{3} \mathrm{~S} / \mathrm{C}_{2} \mathrm{~S}$ & $17.71^{\mathrm{c}} \pm 0.04$ & $12.67^{\mathrm{b}} \pm 0.06$ & $1.5^{\mathrm{a}} \pm 0.020$ & $130904.458(0.000)$ \\
\hline
\end{tabular}

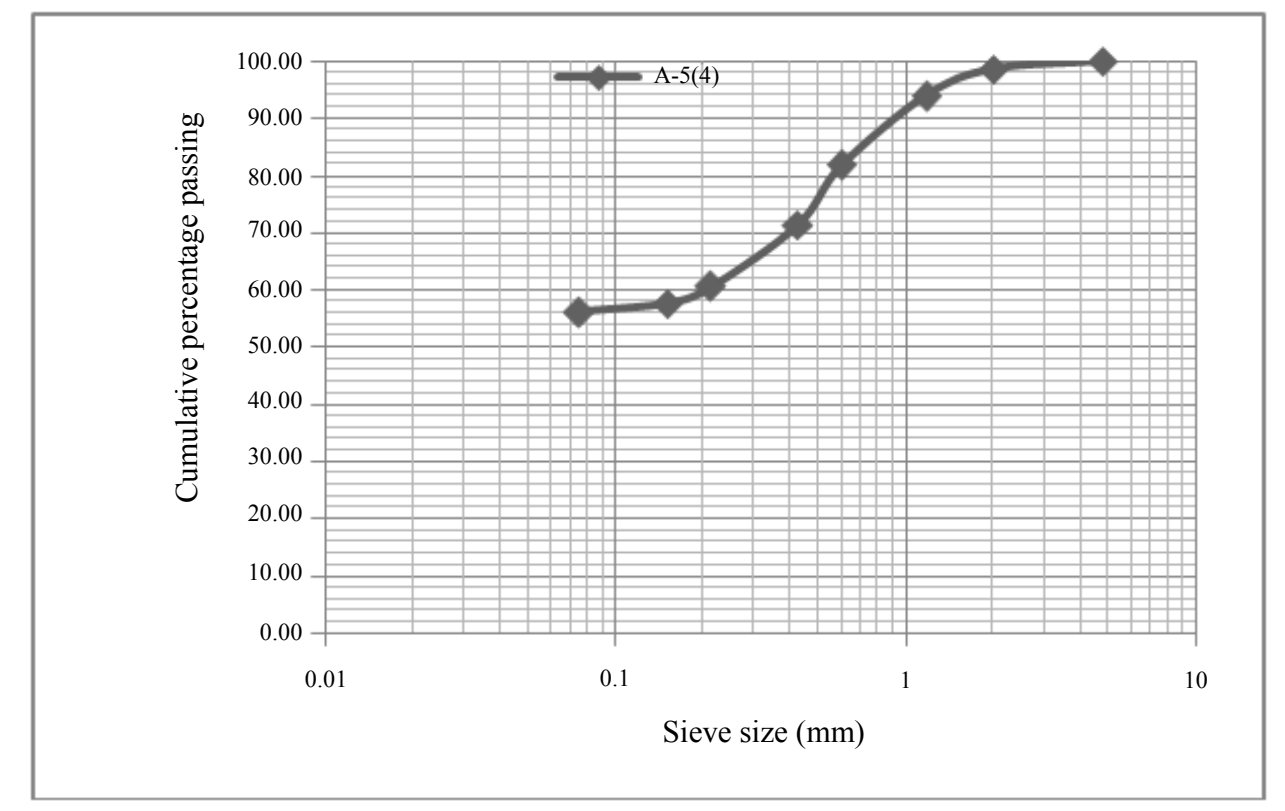

Fig. 1: Graph of Sieve Analysis for the soil sample
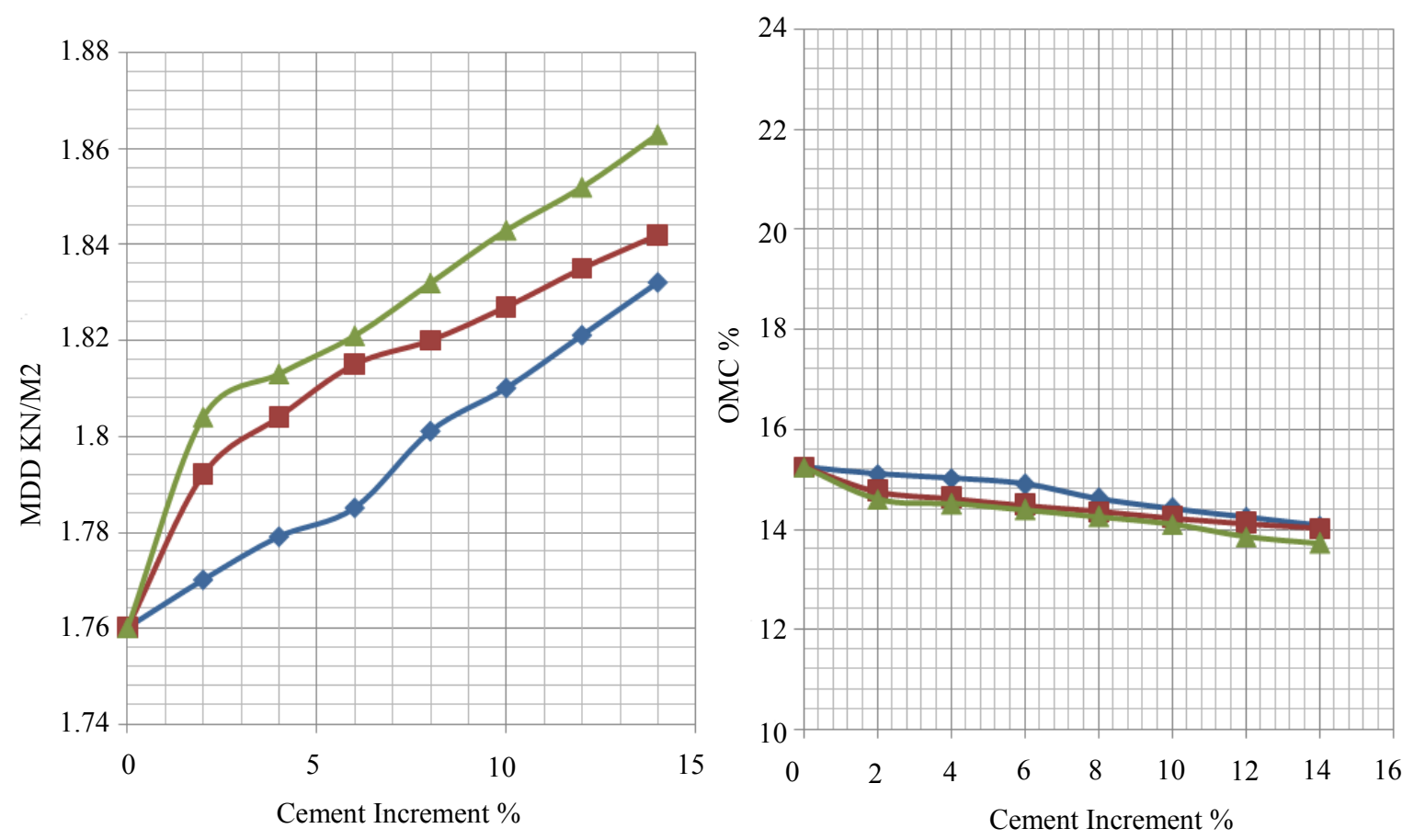

Fig. 2: Graphs Showing the Influence of the Cement on MDD and OMC 
Odumade Adegboyega Oduniyi et al. / American Journal of Engineering and Applied Sciences 2018, 11 (2): 783.791 DOI: 10.3844/ajeassp.2018.783.791
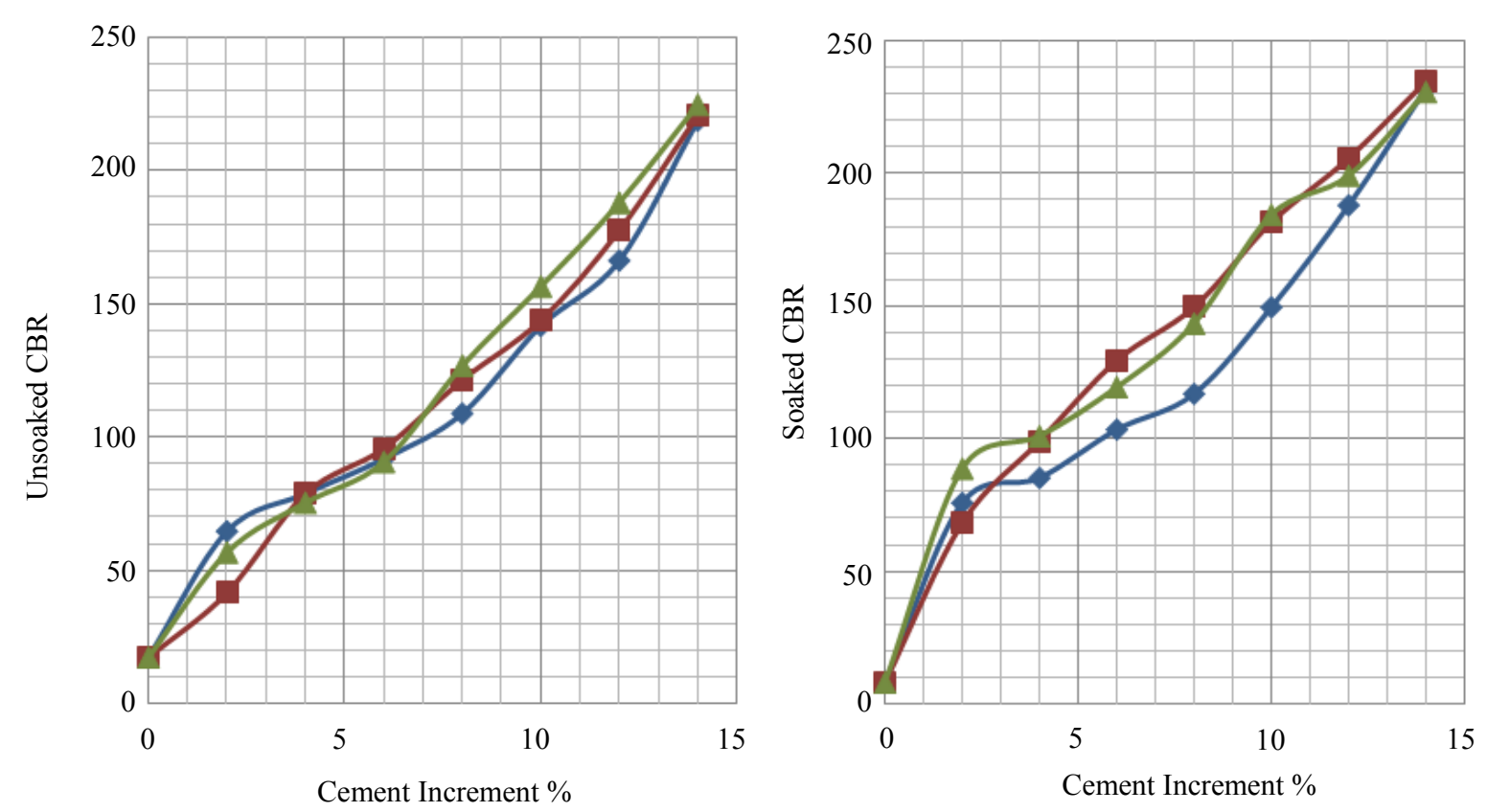

Fig. 3: Graph Showing the Influence of Cement on Unsoaked and Soaked CBR

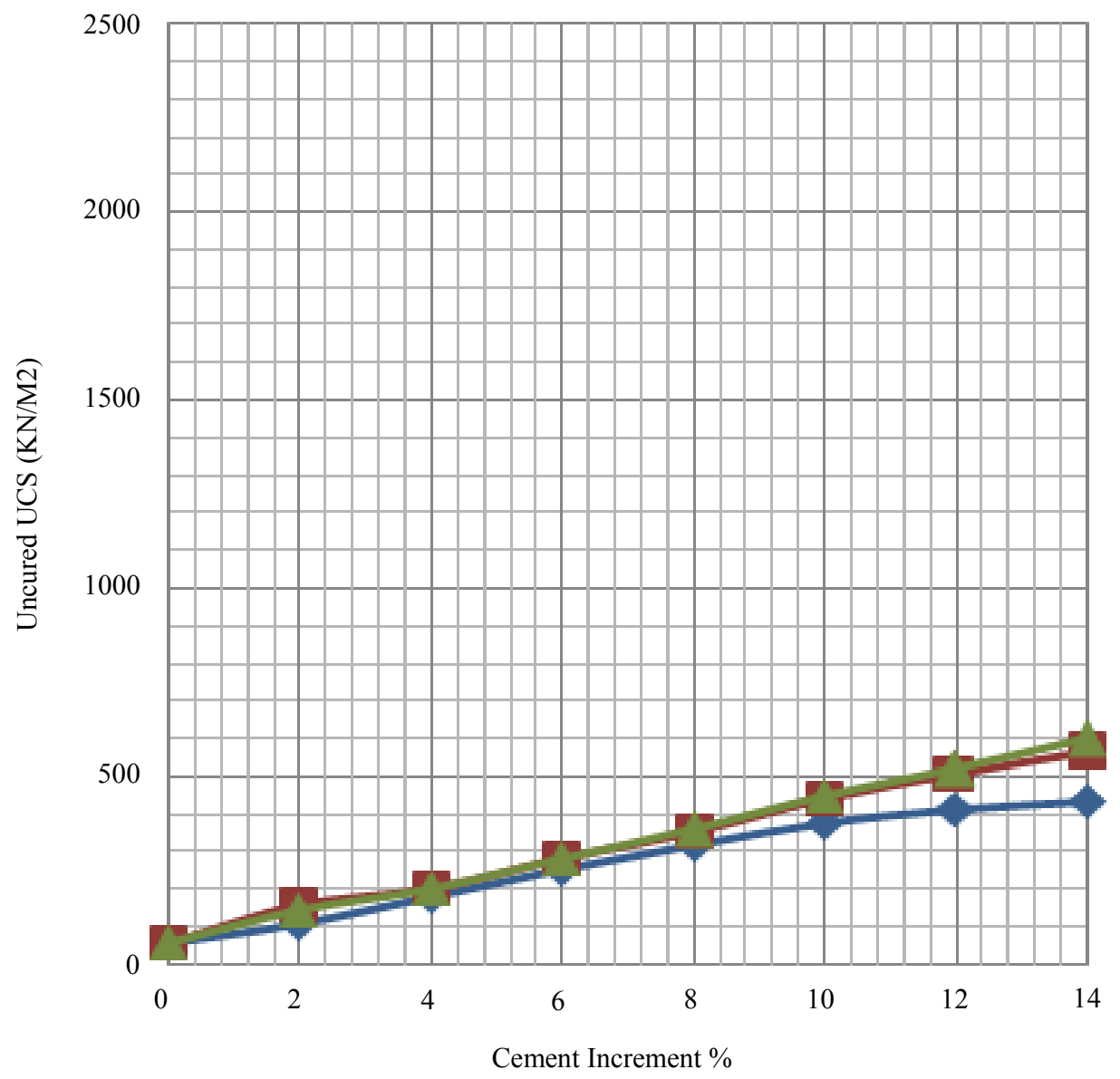

Fig. 4: Graphs Showing the Influence of Cement on UCS for uncured samples 


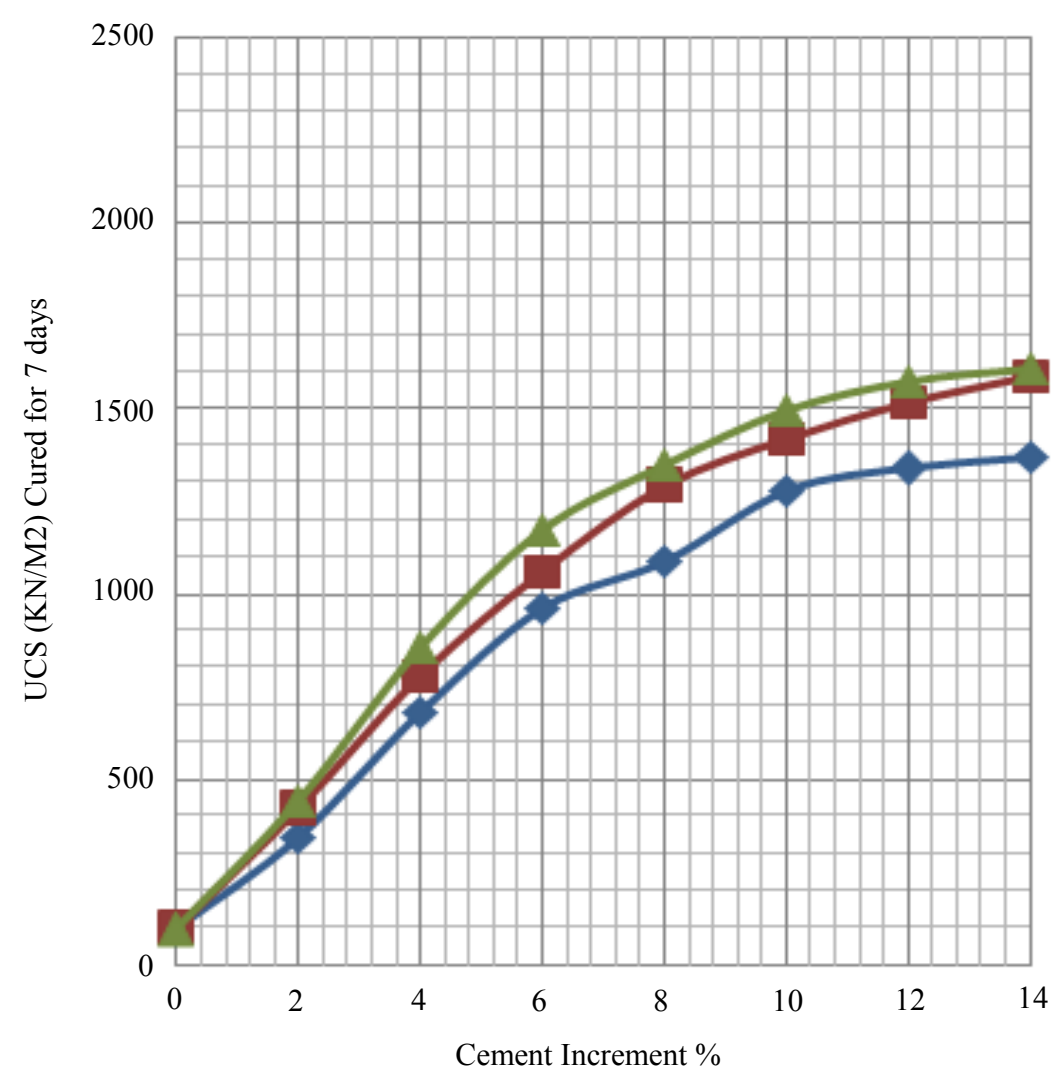

Fig. 5: Graphs Showing the Influence of Cement on UCS for samples cured for 7 days

\section{Discussions}

The three cement types considered in this research work were observed to differ in chemical and metallic content and composition.

\section{Properties of Aggregates and Water}

The soil sample considered is inorganic clay with medium plasticity which according to AASHTO is graded as A-5(4) soil. A-5(4) laterite is discovered from the chemical analysis to have a high quantity of $\mathrm{SiO}_{2}$ and $\mathrm{Al}_{2} \mathrm{O}_{3}$ a lesser loss on ignition (Table 1). The water used for the work waspotable water.

\section{Chemical Constituents of Cement Samples}

The results of the chemical composition of the tested cement samples are shown in Table 1 and these are seen to agree with standards for ordinary Portland cement asspecified in BS 12 and theresults of the compliance check are seen in Table 3 . The total concentration in percentage for the cement samples A, B and Cinvestigated are 95.27, 95.91 and 97.98\% respectively. These results indicate impurities of 4.73 , 4.09 and $2.02 \%$ for samples $\mathrm{A}, \mathrm{B}$ and $\mathrm{C}$ respectively which presents sample $\mathrm{C}$ as the purest of all based on the very low level of impurities discovered.

\section{Effect of $\mathrm{CaO}+\mathrm{SiO}_{2}$}

Table 3 indicates that cement sample A, B and C respectively have $\mathrm{CaO}+\mathrm{SiO}_{2}$ values of $83.41,84.09$ and $86.03 \%$, which complied with the specification of BS 12 forthe addition of $\mathrm{CaO}$ and $\mathrm{SiO}_{2}$ obtained from the chemical analysis of ordinary Portland cement which is expected to be more than $50 \%(\mathrm{~m} / \mathrm{m})$. The three cement samples considered are observed to satisfy this requirement. Figure 2 shows that cement sample $\mathrm{C}$ has the highest values of MDD, followed by sample $\mathrm{B}$, while sample $A$ has the least values of MDD. Figures 3 and 4 also show that cement sample $\mathrm{C}$ has the highest set of CBR and UCS values respectively, followed by sample $B$, with cement sample A having the least set of CBR and UCS valuesrespectively. The results show that the $\mathrm{CBR}$ and UCS values increases as the $\mathrm{CaO}+\mathrm{SiO}_{2}$ content increases which can be produced with the cement when maintained under the same conditions. This is in line with the position of literature that both $\mathrm{CaO}$ and $\mathrm{SiO}_{2}$ aid the strength ofcement stabilized soiland concrete and can be validated by the research carried out by Arimanwa et al. (2016).

\section{Effect of $\mathrm{CaO} / \mathrm{SiO}_{2}$}

According to $\mathrm{BS} 12$, the ratio of $\mathrm{CaO}$ content to $\mathrm{SiO}_{2}$ contents in ordinary Portland cement is expected to be 
more than 2. It is observed from this research that the three samples investigated satisfied this requirement. The results of $\left(\mathrm{CaO} / \mathrm{SiO}_{2}\right)$ as seen in Table 3 for cement samples A, B and $\mathrm{C}$ are 3.19, 3.13 and 2.87 respectively.It is also observed from the results that the higher the sum of $\left(\mathrm{CaO}+\mathrm{SiO}_{2}\right)$ and $\left(\mathrm{CaO} / \mathrm{SiO}_{2}\right)$ of a cement sample thehigher the UCS value of the cement - laterite mix which can be produced from it. The values of the sum of $\left(\mathrm{CaO}+\mathrm{SiO}_{2}\right)$ and $\left(\mathrm{CaO} / \mathrm{SiO}_{2}\right)$ for the three samples $\mathrm{A}, \mathrm{B}$ and $\mathrm{C}$ considered are 86.76, 87.22 and 88.90 respectively. BS 12 gave the limit of the ratio of lime to silicon dioxide in order toensure that the quantity of silicon dioxide is reasonably low compared to that of lime so that the setting of the cement - laterite mixis not inhibited, this can also be validated by the work of Arimanwa et al. (2016).

\section{Influence of $\mathrm{MgO}$}

According to BS 12, Magnesium oxide content in ordinary Portland cementis expected to be not more than 5\% (Priyadarshana and Dissanayake, 2012). The three samples $\mathrm{A}, \mathrm{B}$ and $\mathrm{C}$ considered gave values of $\mathrm{MgO}$ of $2.17,2.04$ and $2.75 \%$ respectively; this shows that the three samples meet the requirements. Magnesium oxide is known to influence the colour of cement and aid the hardness of the resulting mix. Cement with the highest $\mathrm{MgO}$ content isexpected to produce the mix with the highest compressive strength since $\mathrm{MgO}$ contributes to hardness ofmix (Arimanwa et al., 2016).

\section{Influence of $\mathrm{SO}_{3}$}

The sulphur trioxide $\left(\mathrm{SO}_{3}\right)$ content in ordinary Portland cement is expected to be not more than 3.5 $(+0.1) \%$ according to BS 12 . The threesamples A, B and $\mathrm{C}$ considered satisfied this requirement with $1.02,1.14$ and $1.23 \%$ respectively according to Table 1 . This shows that sample $\mathrm{C}$ has more of Sulphur trioxide $\left(\mathrm{SO}_{3}\right)$ and this can be considered to contribute to the fastest initial setting time of sample $\mathrm{C}$ cement paste, as $\mathrm{SO}_{3}$ is known to aid the setting time of cement and contribute to soundness (Arimanwa et al., 2016).

\section{Effect of $\mathrm{Al}_{2} \mathrm{O}_{3}$}

Table 1 shows that the three cement samples have aluminium oxide $\left(\mathrm{Al}_{2} \mathrm{O}_{3}\right)$ content of $4.92,4.08$ and $6.08 \%$ respectively for samples $\mathrm{A}, \mathrm{B}$ and $\mathrm{C}$. Cement sample $\mathrm{C}$ is seen to contain the highest quantity of $6.08 \%$ of $\mathrm{Al}_{2} \mathrm{O}_{3}$ which also shot high the initial setting time of the cement paste as aluminium oxide $\left(\mathrm{Al}_{2} \mathrm{O}_{3}\right)$ is known to aid the quick setting of cement (Arimanwa et al., 2016).

\section{Influence of $\mathrm{Fe}_{2} \mathrm{O}_{3}$}

Iron oxide $\left(\mathrm{Fe}_{2} \mathrm{O}_{3}\right)$ influences cement colour and contributes to the bonding of the different ingredients (Arimanwa et al., 2016). The $\mathrm{Fe}_{2} \mathrm{O}_{3}$ contents for the three samples A, B and C considered are $0.75,0.91$ and $1.24 \%$ respectively as seen in Table 3 .

\section{Effect of Residues}

British standards consider $\mathrm{Na}_{2} \mathrm{O}, \mathrm{K}_{2} \mathrm{O}, \mathrm{TiO}_{2}$ and $\mathrm{P}_{2} \mathrm{O}_{5}$ in ordinary Portland cement as residues and limit the addition of these impurities to $5 \%$. The three samples A, $\mathrm{B}$ and $\mathrm{C}$ considered were observed to satisfy this requirement with total residue contents of $0.75,1.03$ and $0.8 \%$ respectively.

\section{Result of Statistical Model}

The Anova test results indicates that there were significant differences between the samples considered thereby giving a" $p$ " value $<0.05$ indicating significant variation in the chemical composition of cements and the unconfined compressive strength.

\section{Conclusion}

The chemical composition of cement determines to a great extent the performance of the cement when mixed with other materials such as laterite in atropical region. The bearing capacity and unconfined compressive strength values of the laterite - cement mix increases as thelime $(\mathrm{CaO})$ and Silicon Dioxide $\left(\mathrm{SiO}_{2}\right)$ content in cement increases. Cement sample $\mathrm{C}$ has the highest unconfined compressive strength value and bearing capacity, while also having the highest values of lime and silicon dioxide.

The value of the Aluminium Oxide $\left(\mathrm{Al}_{2} \mathrm{O}_{3}\right)$ and sulphur trioxide $\left(\mathrm{SO}_{3}\right)$ determines how fast the cement paste sets. The higher the Aluminium Oxide $\left(\mathrm{Al}_{2} \mathrm{O}_{3}\right)$ and sulphur trioxide $\left(\mathrm{SO}_{3}\right)$ contents of cement, the faster the setting time. Cement sample $\mathrm{C}$ has the fastest setting time, while also having the highest Aluminium Oxide $\left(\mathrm{Al}_{2} \mathrm{O}_{3}\right)$ and sulphur trioxide $\left(\mathrm{SO}_{3}\right)$ content. Cement with chemical composition as sample $\mathrm{C}$ is concluded and recommended to produce better bearing capacity and unconfined compressive strength than cementswith chemical composition as samples A and B when mixed with laterite in a tropical region.

\section{Acknowledgement}

The authors would like to thank the Editor and the anonymous reviewers for their constructive comments and suggestions for improvement of this paper.

\section{Author's Contributions}

Odumade Adegboyega Oduniyi: Methodolgy and discussion.

Ezeah Chukwunonye: Coresponding author: Literature review and environmental context.

Charles Nnamdi Ezugwu: Introduction and recommendation.

Ekeoma Emmanuel: Data Analysis. 


\section{Ethics}

This material has not been published in whole or in part elsewhere; all authors have been personally and actively involved in substantive work leading to the manuscript, and will hold themselves jointly and individually responsible for its content.

\section{References}

AASHTO T193, 2013. Standard Method of Test for the California Bearing Ratio. 1st Edn., AASHTO, Washington DC.

Ahmad, S., 2002. Effect of fineness of cement on properties of fresh and hardened concrete. Proccedings of the 27th Conference on our World in Concrete and Structures, Aug. 29-30, CI-Premier PET LTD, Singapore, pp: 1-8.

Akiije, I., 2014. Trength and permeability characteristics of select ed laterite stabilized using powermax cement. Int. J. Sci. Eng. Res., 5: 695-702.

Amin, A.H., 2004. Influence of the $\mathrm{SO}_{3}$ content of cement on the durability and strength of concrete exposed to sodium sulfate environment. PhD Theses of Philosophy, University of Florida, America.

Arimanwa, M.C., D.O. Onwuka and J.I. Arimanwa, 2016. Effect of chemical composition of ordinary portland cement on the compressive strength of concrete. Int. Referred J. Eng. Sci., 5: 20-31.

ASTM C150/C150M -17, 2017. Standard Specification for Portland Cement. 1st Edn., ASTMInternational, West Conshohocken, PA.
Jaritngam, S., O. Somchainuek and P. Taneerananon, 2014. Feasibility of laterite-cement mixture as pavement base course aggregate. Int. J. Sci. Technol., 38: 275-284.

Krishna, R., 2002. Engineering properties of soils based on laboratory testing. UIC, 44: 44-59

Odumade, A.O., C. Ezeah and O.O. Ugwu, 2018. Performance analysis of cement-stabilised laterite for road construction in the tropics. Environ. Geotechnol. DOI: 10.1680/jenge.17.00026

Olaniran, O.J., 1991. Evidence of climatic change in nigeria based on annual series of rainfall of different daily amounts, 1919-1985. Climat. Change, 19: 319-340. DOI: 10.1007/BF00140169

Priyadarshana, T. and R. Dissanayake, 2012. Variation in cement properties and its effect on quality of concrete. International Institute of Infrastructure Resilience and Reconstruction.

Solanki, P. and Z. Musharraf, 2012. Microstructural and Mineralogical Characterization of Clay Stabilized Using Calcium-Based Stabilizers. In: Scanning Electron Microscopy, Kazmiruk, V. (Ed.), IntechOpen, pp: 772-798.

Taylor, H.F.W., 1997. Cement Chemistry. 2nd Edn., Thomas Telford Publishing, London, UK, ISBN-10: 0727725920, pp: 459. 